\title{
The Total Quality Management in Banking
}

\author{
Manal Mansour Alharth ${ }^{1}$, Zubaida Abdulaziz Jastania ${ }^{2}$, Azrilah Abdul Aziz ${ }^{3}$ \\ Department of Information Systems, Faculty of Computing and Information Technology, King Abdulaziz University, \\ Jeddah, Kingdom of Saudi Arabia ${ }^{1,2,3}$
}

\begin{abstract}
This study aims to identify the impact and characteristic of the total quality management in banking services, highlight the importance and role of quality banking services as an entry point to increase the competitiveness of banks, and seeks to draw the attention of the importance of benefiting from the application of TQM in banking sector.
\end{abstract}

Keywords: Total Quality management, Banking sector, quality work life, service quality.

\section{INTRODUCTION}

Total Quality Management (TQM) considered as a main tool that leads to the strategy of developing work and improving performance in order to achieve profitability through good services and quality products. It can be defined as the continuous improvement of administrative and productive processes through reviewing and analysing the results achieved, and searching for other means and methods to raise the level of performance and try to reduce the time and effort for the completion of production processes by eliminating all unnecessary functions for consumers and for the productive process to reach the required level of total quality [1].

In order to achieve the competitive quality level, it is necessary to use many methods and skills of quality's science. Choosing the appropriate method or the effective and useful tool is related to many factors and circumstances of the establishment internally and externally.

Continuing Quality Improvement can be considered as the only way to improve the performance of organizations and banks. Quality's sciences and its various methods helps to achieve gains for banks by ensuring distinguished and constantly evolving services using quality improvement techniques, to reduce problems and errors through the quality control methods to detect any defect in inspection to prevent its development and to detect the causes and remove them as soon as possible, It even can avoid the error or problem before it happened, which helps the bank to maintain its basic customers and gain the largest possible number of new customers.

\section{THE CONCEPT OF TQM IN BANKING INDUSTRY}

(Quality management becomes a significant aspect especially in a competitive sector like banking. The concept of banking TQM has developed over years to include more improvements and service relationships with customers. Adding to that, the huge development in the technology sector makes it necessary to focus on the continuous improvements of electronic and online services. The concept of banking service quality includes many other aspects, but all of them can be divided into four conceptual categories: customer service, banking services, electronic services, and automated services [2].

It is important to realize the relationship between the customer and employee perceptions about TQM in banking sector in order to decrease the distance between them.

\section{A. Customer perception about TQM in bank}

Banking is one of the biggest sectors that serve almost all people from different strata of society which have different perceptions and expectations about banking service quality. Customer builds a picture of banking quality depending on the relative difference between the expectation on the service performance and the actual experience of the service itself. Usually, customer's expectations regarding service quality are based on his personal view and his previous experience with other service providers [3].

Banking institutions must realize what is the value expected by the customers and what customers are looking for in order to rise their level of satisfaction and keep their loyalty. From customers' viewpoint, the expected value is related to several factors [4]:

- $\quad$ Banking services

Values expected are: accessibility, accuracy, flexibility, and the ease of performing

- $\quad$ Bank staff

Values expected are: professionality, qualification, kindness, and speed of service

- $\quad$ Image value

Values expected are: reliability, bank reputation, and bank participation in social Initiatives 


\section{- $\quad$ Money expenses}

Values expected are: reasonable costs of service and interest of loans

- $\quad$ Time and energy expenses

Values expected are: advanced and efficient network of branches and ATMS, working hours, waiting time, and request fulfilment time

Customers evaluate these factors depending on two scales: to what extent this factor is important for them? And to what extent it satisfies their expectations. Evaluation results may differ from one customer to another, but it all contributes to improve the banking quality.

\section{b. $\quad$ Employees perception about TQM in bank}

Human resources are a significant part of any organization success especially the front office employees who are responsible of building relationships with customers and keep their loyalty. It is self-evident that employees cannot deliver a good value to the customer unless they have a good quality of work life (QWL). QWL is a substantial term which refers to the different methods that focus on raising the levels of employees' satisfaction rather than just focusing on the quality of services they provide. It is very critical for organizations to focus on the overall development for its staff and ensure their happiness at the same time to make a good balance between their job performance and personal life. This healthy balance is important to reduce the employees stress and make a great motivation for them to perform in the best possible way [5].

Every organization has its own methods to improve the quality of work life, but there are eight broad criteria of employment that considered as necessary factors for all employees from different sectors including the bank sector [6]:

- Appropriate and fair compensation.

- Safe and healthy work environment

- Enhancing the personal capabilities and skills Opportunity for promotions

- Good balance between work and social life

- Organizing the work in a constitutional way

- Protecting employees' rights

- Social relevance of work life

For bank sector, there are additional aspects must be taken into account to improve the QWL. Effective management give all the employees a chance to contribute in decision making process to improve the general performance and to make them feel that success is everyone's mission. Employees' appreciation is also a significant aspect and it is not only about providing good salaries to the employees but recognizing their work, giving them enough benefits and bonuses according to their productivity. It is also important for banks to ensure providing all facilities that help to do the work as required and provide suitable solutions for all kinds of problems. Banks should make a healthy competitive environment for their employees and encourage them to develop their capabilities and skills which will help them to reach the maximum success [5].

Improving QWL faces many difficulties like opposition to change, high costs, fear of less productivity, unfair competition and staff comparison, regional prejudice, and distrust of evaluation criteria and promotions. All these could hinder banks from achieving a good QWL for employees which leads to decreasing their enthusiasm to work and providing highest effort to reach the organization's goals [6].

\section{III.TQM IMPLEMENTATION IN BANKING SECTOR}

Achieving a competitive quality level requires using many methods, tools, and skills of quality science which may differ from bank to bank according to its conditions internally and externally and it may need to change over time. Implementation of TQM necessitates introducing quality systems that meets the constantly changing requirements of the customers. Quality management systems focus on quality planning by setting quality policy and objectives which will help to choose the appropriate quality techniques and methods. These systems must be created in particular and it needs training programs, including senior management, middle management and the rest of the employees. Once specific objectives have been reached, new improvement targets are set to keep continuously upgrading of performance level. It is worthy to mention the necessity of having a high professional management team that can successfully manage the whole process of improving the quality [1].

TQM in banks is a wide issue that includes many dimensions that must be considered when implementing quality [7]:

- Reliability

Completing operations efficiently and effectively from the first time to win the customer trust

- $\quad$ Response level

The rapid response of employees to the customers' demands and decreasing the delay as possible as it can 
- $\quad$ Employees' qualification

Staffs have adequate capabilities to provide a distinct service to customers.

- Accessibility

Easy access to the service providers and contact them

- Communication

Exchanging of service information between service providers and customers

- $\quad$ Priority

Taking into consideration the interests and needs of customers.

- $\quad$ Safety

Preparing for potential risks and making suitable plans to face any kinds of problems

- Caring

Making all efforts to comfort the client

- $\quad$ Physical Material and human

The outward appearance of equipment and personnel

\section{IV.THE IMPACT OF TOTAL QUALITY MANAGEMENT IN BANKING SECTOR}

The benefits and effects of the TQM on organization performance have encouraged the banks to focusing in the quality of services that they provide and how it will help them to succeed.

The quality of services plays an important role and primary factor in ensuring the survival of the bank with the other competitors in the market. Customers have a wide range from banks and they would only choose the banks that provide best services in terms of quality, reliability, and profitability and bank which is at par with international standards. [2].

Maximizing customer satisfaction through quality customer service has been described as the ultimate weapon by Davidow and Vital (1989). [8]

The TQM is extremely important to achieve the quality, providing a best service can be considered as pre-requisite to survive and success of banking sector since the performance of banks is significantly and positively linked with the service quality. [2]

\section{A. Service quality in banking}

Quality of service is considered as critical issue in preserving and propagates business in the competitive marketplace. In the current trend of trade globalization, service-based companies like banks must provide excellent service to their customers to get a sustainable competitive advantage. [9] Quality in banks does not mean to just satisfy customers' expectation but exceeding their expectations since the customer's' perception about the quality has been changing over the years. Today, there are many aspects of banking services quality like technology based services, improved and new product services and e-services. Therefore, the Banks have to commit towards continuous improvement of their service that provided to customers. There are three conceptual categories related to internet banking service quality [2] [10]:

- Customer service quality

- Banking service product quality

- Online/internet/e-service quality

1) Customer service quality: The main factor in assessing the performance of banks is the quality of their services (quality: customer or client satisfaction). A common definition, proposed by Parasuraman, Zeithaml and Berry "is that customer service quality is the deference between the bank's performance as perceived by the customer and the level of performance that the customer expected " [11]

The current global trend is to satisfy the client's expectations in terms of quality is to achieve his satisfaction, and to ensure continuous improvement of quality to keep the outstanding performance against competitors.

In the era when technology can facilitate the intense competition, it is necessary for the banks to focus on improving, controlling and measuring their service quality continuously. Therefore, any bank that seeks excellence must achieve a distinguished level of service that meets the ever-changing requirements of its customers to satisfy them. This can only be achieved through the introducing of quality systems that initially required training program for senior management, middle management and the rest of the employees. In addition, the banks should emphasize deeper permeation of the current customers' database since the data about customers and their needs can help the industry to identify the existing key customers, future customer and building relationship with them. [2]

2) Banking service product quality: Banking service product quality plays an important role in determining customers' perceptions of the overall banking service quality, and it is primarily associated with product variety and 


\section{IARJSET

diverse features. Banking service product quality must tend to provide the best services without knowing what the customers really want and expect from them. [12] This service may vary from financial transactions, paying bills electronically and automatically, viewing their balance, monthly bank statements, purchasing shares and insurance, home loans with minimum rate of interest, purchasing cars and lands. And the bank customer wants these services at one site with ease. Differentiation and innovation in the quality of bank products can be the key of attracting new customers and enhancing customers' satisfaction. Therefore, it may contribute to the competitive advantage in the banking industry. [2] [10]

3) Online/internet/e-service quality: The growth of internet and information system led to appearance of the eservices concept, therefore the way of interaction between the bank and the customer changed. Cost reduction and delight customers through automation are the basic reason behind development of online service. [2]

The article by Liu and Arnett [13], considered the four quality factors as major ingredients for the success of website as: system use, system design quality, information quality and playfulness.

There many factors can affect the using of the e-services like difficulty in using and security concern [14]

Santos discussed e-service quality dimensions as consisting of, ease of use, web-appearance, linkage, structure and layout, content as the incubative dimensions; reliability, efficiency, support, communication, security, and incentive as active dimensions. These dimensions can be considered as major determinants of consumer's quality perception and it can provide the banks with a promising starting point for establishing an effective quality management for their e-services. [15]

\section{QUALITY EVALUATION}

Successful banks are very interested to improve the quality of its services and keep their competitive level and it uses many tools to evaluate the service quality and convenience. Tools are selected very carefully to meet the goals and there are some techniques that help to choose the appropriate evaluation criteria like Categorical based Evaluation Technique which help banks to come up with the suitable quality evaluation system. MACBETH is an approach that helps to quantify the relative attractiveness of selections by creating a numerical scale and weights for criteria. It uses qualitative (non-numerical) values which represent experts' judgments and build a new quantitative (numerical) value model [16].

Financial ratio is another way to evaluate the quality of banks which used to measure the financial performance. This analysis focuses on the profitability performance ratios like [17]:

- $\quad$ Return on asset

The ratio between the income earned and the assets used

- $\quad$ Return on Deposits

The ratio between profits and the total deposits

- $\quad$ Return of equity

The ration between the profit and money invested by shareholders

- $\quad$ Liquidity Performance

The ration of the bank ability to pay its obligations

- Total Loans to Total Deposits Ratio

The ration between banks total loans and its total deposits

- Total Deposits to Total Assets Ratio

The ration between banks total loans and its total assets

\section{VI.CONCLUSION}

Banks and its privacy, sensitivity and how it can be affected by the mistakes is in dire need of applying the quality with its systems, methods and tools which helps to detect errors in a timely manner to address them, avoid repetition by knowing the root causes of errors, and take necessary to remove these reasons by controlling all internal processes.

The quality tools and methods can help the banking institutions to develop and improve their performance continuously and this is necessary in the current competitive environment which is characterized by striving for the best.

Quality is not a concept that is seen as a single unit, but a multidimensional concept and aspects,

These dimensions must be first identified, then focused on, studied and analyzed to ensure that they are available in the desired form to achieve the best service to avoid neglecting of any dimension that may affect the reputation of the institution and its competitive position. 


\section{REFERENCES}

[1] M. Jammal, S. Khoja and A. Abd.Aziz, "Total Quality Management Revival and Six Sigma," International Journal of Computer Applications, vol. 119, no. 8, pp. 1-2, 2015.

[2] F. Talib,. Z. Rahman and M. Qureshi, "Impact of Total Quality Management and Service Quality in the Banking Sector," J Telecommun Syst Manage, vol. 1, no. 2, pp. 1-2, 2012.

[3] S. Tandon and A. Thakur, "Customers' perception about total quality management in banking sector: a comparative study in Punjab region," Strategic Human Resource Management, vol. 1, no. 2, 2012.

[4] J. Titko and N. Lace, "Bank Customers' and Employees' perceptions of Value," Scientific Journal of Riga Technical University, vol. $21,2011$.

[5] L. Kumari, "Bank employees' perception about quality of work life and its impact on job behavior in district Ludhiana," Indian Journal of Commerce \& Management Studies, vol. IV, no. 2, 2013.

[6] A. JAYAKUMAR and . K. KALAISELVI, "Quality of work life-an overview," International Journal of Marketing, Financial Services \& Management Research, vol. 1, no. 10, 2012.

[7] T. OKEKE, G. EZEH and. N. UGOCHUKWU, "Service Quality Dimensions and Customer Satisfaction with Online Services of Nigerian Banks," Journal of Internet Banking and Commerce, vol. 20, 2015

[8] M. Nagabhushanam, "A Study on Customer Service Quality of Banks in India," 2010.

[9] B. M. AWUOR, "Service quality and customer satisfaction in the banking ssctor in Kenya," 2014.

[10] S. C. Minjoon Jun, "the key determinants of Internet banking service quality: a content analysis," international Journal of Bank Marketing, vol. 19, no. 7, pp. 276-291, 2001.

[11] V. A. Zeithaml, A. Parasuraman and L. L. Berry, "A conceptual model of service quality and its implications for future research," Journal of Marketing, vol. 49, no. 4, pp. 41-50, 1985.

[12] J. M. Sahut and Z. Kucerova, "Enhance Internet Banking Service Quality with Quality Function Deployment Approach," The journal of internet banking and commerce.

[13] K. P. A. Chang Liu, "Exploring the factors associated with Website success in the context of electronic commerce," information and management, vol. 38, no. 1, pp. 23-33, 2000 .

[14] S. M, "Adoption of Internet banking by Australian consumers: an empirical investigation," International Journal of Bank Marketing, vol. 17, pp. 324-334, 1999.

[15] M. H. a. T. F. Hans H. Bauer, "Measuring the quality of e-banking portals," International Journal of Bank Marketing, vol. 23, no. 2, 2005.

[16] F. Ferreira, S. Santos, R. Paulo and R. Spahr, "Evaluating retailbanking quality service and convenience with MCDA techiques: A case study at the bank branch level," 2011.

[17] M. Hassan, "Evaluating the Financial Performance of Banks Using Financial Ratios- A Case Study of Erbil Bank for Investment and Finance," European Journal of Accounting Auditing and Finance Research, 2014. 